\title{
The Role of Humanitarian Cooperation in the Formation of Interethnic Relations Between Turkey and the Countries of Central Asia (From 1991 to 2020)
}

\author{
Valentin Moskalenko ${ }^{1 *}$ \\ ${ }^{1}$ Moscow State Institute of International Affairs (MSIIA) of the Ministry of Foreign Affairs of the Russian Federation, \\ Russia \\ *Email: moskalenkoolga@mail.ru
}

\begin{abstract}
The article is devoted to identifying and substantiating the nature of the role of humanitarian cooperation in the formation of interethnic relations between Turkey and the countries of Central Asia (from 1991 to 2020). The relevance of the study lies in the attractiveness of Central Asia as the richest resource-possessing region with significant human potential and multifaceted historical and cultural heritage, having the experience of living as an ethnic group both independently and within large states. Thirty years of experience in the existence of the countries of Central Asia as states with independent political status allows us to analyze the experience of their humanitarian cooperation with other countries on the example of Turkey as a country that has common linguistic, cultural and religious roots with the Central Asian countries. The aim of the study was to identify the role of humanitarian cooperation in the formation of inter-ethnic relations between Turkey and the countries of Central Asia from 1991 to 2020. We set the following tasks: to analyse the humanitarian cooperation from the position of comparative political science, identify its main components as a system - markers for the study of the role of humanitarian cooperation in the development of interethnic relations as well as to describe the features of Turkey's humanitarian cooperation with the countries of Central Asia from 1991 to 2020. To analyze the role, we identified the following markers: strategic and tactical goals of humanitarian cooperation; actors and motivators of this process, the presence of third countries; the state of the economic, financial, socio-political and national spheres of the donor state of cooperation; resources and potentials of both the recipient country and the donor power of humanitarian cooperation, the latter's obligations to other countries and blocks. As a result, we retrieved the following features of humanitarian cooperation between Turkey and the countries of Central Asia: unclear thoughtfulness and weak interconnection of the strategy and tactics of this cooperation; lack of a system and dynamics of the goals of this cooperation; Turkey has insufficient own funds and resources to invest in the economy and economy of Central Asian countries; priority of its own Turkish interests, interest in permanent unchanging double alliances in the absence of other alliances and blocks, Turkey also has the right to change its goals and intentions, as well as allies. This made it possible to determine the nature of a more positive and constructive role. Research prospects are presented in a comprehensive comparative political study of the interaction between Turkey and the countries of Central Asia.
\end{abstract}

Keywords: Interethnic relations, Turkey, Central Asian countries, humanitarian cooperation.

\section{INTRODUCTION}

The relevance of the study of humanitarian cooperation and the formation of interethnic ties between Turkey and the countries of Central Asia lies in the fact that the countries of Central Asia in the 21st century are increasingly attracting attention from both the global world powers - the USA, China, Russia, and foreign policy and military blocks - EU, NATO, BRICS, LAS, CIS, GCC, OIC. Turkey occupies a special place in this process, as it has common historical and religious roots with the countries of Central Asia through Islam and the 
Turkic language community. Moreover, the idea of reviving the Ottoman Empire - the idea of neoOttomanism in Central Asia is increasingly attracting the leading representatives of business and politics in Turkey. On the other hand, the countries of Central Asia, having received the status of an independent country and having existed for thirty years as sovereign states, began to more clearly measure their place in the world, more thoroughly understand cooperation and assistance provided by other countries and blocks.

Therefore, the study set the goal of identifying the role of humanitarian cooperation in the formation of interethnic ties between Turkey and the countries of Central Asia from 1991 to 2020.

The objectives of the research are: to analyze humanitarian cooperation from the perspective of comparative political science and to identify the main components of the system of humanitarian cooperation and markers for studying the role of humanitarian cooperation in the development of interethnic relations; reveal the main features of Turkey's humanitarian cooperation with the countries of Central Asia from 1991 to 2020 and draw a conclusion about the nature of Turkey's role in the development of interethnic relations with the countries of Central Asia.

The object of the research is the process of forming interethnic ties between Turkey and the countries of Central Asia, while the subject of the research is humanitarian cooperation in the process of forming interethnic ties between Turkey and the countries of Central Asia.

The research methods were theoretical comparative analysis of sources, structural and functional, institutional, systemic, civilizational and cultural events and forms of humanitarian cooperation between Turkey and countries of Central Asia, including observation of the population of Turkey and Central Asian countries (2010-2020)).

\section{METHODOLOGY}

The research methodology is based on the methodology of a comparative political study of the problem of interethnic relations and humanitarian cooperation as a political problem of international relations, global and regional development.

Comparative political science study of the problem makes it possible to systematize the assessment of humanitarian cooperation and interethnic relations from the standpoint of Turkey and the countries of Central Asia to identify the features of these processes and define the role of humanitarian cooperation in interethnic relations between Turkey and the countries of Central Asia from 1991 to 2020. Comparative analysis allows us to objectively present all aspects of humanitarian cooperation between Turkey and the countries of Central Asia, as well as to classify the features of this cooperation and predict the process of forming interethnic relations. The object of comparison is the attitude of Turkey and the Central Asian countries to humanitarian cooperation and the process of forming interethnic relations. The object of comparison is the attitude of Turkey and the Central Asian countries to humanitarian cooperation and the process of forming interethnic relations. The first includes a system of directions and forms of humanitarian cooperation, the second - socio-political and economic problems, for the solution of which we might use appropriate measures and forms of humanitarian cooperation.

We used the following methods of political science: structural-functional - consideration of humanitarian cooperation as an integral system of a set of structural elements that perform strictly defined functions in this system; institutional - the study of institutions through which we carry out humanitarian cooperation; systemic analysis of humanitarian cooperation as a system; civilizational and cultural - taking into account the influence of civilizational and cultural factors of the Turkish and Central Asian ethnic groups on humanitarian cooperation.

Humanitarian cooperation between countries is understood as "one of the central directions in the modern system of international relations, which aims to preserve life on Earth and ensure a dignified existence for all mankind" (A.A. Mustafin [1, p.34]), and interethnic relations, which goal is the "interaction of several social ethnic communities, contributing to the development of relations between people of different nationalities" [1, p.75].

The basis of humanitarian cooperation is the ongoing humanitarian diplomacy as a branch of international law and international relations, the center of which is the model of sustainable development of society. Humanitarian cooperation is carried out under the auspices of the United Nations in cooperation with the United Nations Office for the Coordination of Humanitarian Affairs, the United Nations High Commissioner for Refugees, the Partial Open Agreement of the Council of Europe, the International Civil Defense Organization, the North Atlantic Alliance and many other international organizations. An integral part of the area of world humanitarian cooperation is the market of humanitarian services in the field of education, culture, science and mass communications. (A.A. Velikaya [2, p.34]). The structure of humanitarian cooperation includes international measures to protect the entire range of human rights, protection of life, health and dignity of mothers and children, cooperation in the fight against disease and hunger, overcoming illiteracy and spreading recognized international standards in the upbringing and education of children and adolescents, humanitarian 
demining, the repatriation of refugees, the improvement of regional civil protection structures, the conduct of joint training and exercises, the development of a mechanism for responding and coordinating the actions of search and rescue units in case of emergencies.

Thus, the system of humanitarian cooperation includes the following areas: culture, education, religion, humanitarian-legal, military-humanitarian, science, mass communications and humanitarian aid in emergency situations.

The activity of humanitarian cooperation depends on many conditions and factors. Firstly, it is the availability of any resources and potentials of the region and the recipient country of cooperation, which can be used in the future by the organizers of humanitarian cooperation either together with the recipient of this cooperation or independently on conditions favorable to the organizers. Secondly, it is the strategic and tactical goals of the actors of humanitarian cooperation and their allies or initiators. The organization of humanitarian cooperation is a costly event and it is not always possible for one power to organize it. Therefore, there may be various third forces that may pursue their goals and objectives, which are not always known to the actor of cooperation. Thirdly, there are capabilities of the actor of humanitarian cooperation - the real state of the economic, financial and sociopolitical spheres of the donor state and its obligations to third countries.

Therefore, it is important to identify the following markers for studying the role of humanitarian cooperation in the development of interethnic relations when analyzing and assessing the real contribution of the organization of humanitarian cooperation:

- strategic and tactical goals of humanitarian cooperation;

- actors and motivators of this process, the presence of third countries - customers, interested parties, allies, etc.;

- the state of the economic, financial, socio-political and national spheres of the donor state of cooperation;

- resources and potentials of both the recipient country and the donor power of humanitarian cooperation, the latter's obligations to other countries and blocks, etc.

This basis is the only one for the assessment of both the overall role of humanitarian cooperation between countries and the contribution of humanitarian cooperation to the development of interethnic relations between countries.

\section{RESULTS OF THE STUDY OF THE ROLE OF HUMANITARIAN COOPERATION IN THE FORMATION OF INTERETHNIC RELATIONS BETWEEN TURKEY AND THE COUNTRIES OF CENTRAL ASIA FROM 1991 TO 2020 AND THEIR DISCUSSION}

The countries of Central Asia that received an independent political status as a result of the collapse of the USSR in 1991 and have a large complex of resources (inexhaustible (climatic) and exhaustible (renewable (water) and non-renewable (mineral)); natural (minerals), economic and labor; industrial, agricultural, potentially ready-to-use and recreational (a set of natural, cultural, social, economic resources for the restoration of spiritual and physical strength of a person)) have become extremely attractive for many countries and blocks (Z.S. Pulatkhodzhaev [3, p.84]).

The ethnic groups of Central Asia were especially attractive since they remained faithful to the Muslim historical foundations of the people, despite more than seventy years of life in the USSR. The following traditions were preserved: Islam as the main religion, clannishness and nepotism as the main criteria for promotion to power structures and further career advancement, the omnipotence of leaders and their administration, etc.

Islamic-Turkic and cultural-ethnic unity attracted Turkey to this region one of the first in mid-December 1991, recognizing the independence of all the new republics of the region and opening consulates in their capitals. The unity helped them, with the support of the United States, to join the system of the Conference on Security and Cooperation in Europe (CSCE). At the same time, the Turkic Agency for Cooperation and Coordination (TACC) was created in 1991 in order to develop multi-vector relations with the Turkic republics and to ensure coordination. Azerbaijan, Kazakhstan, Kyrgyzstan, Uzbekistan, Turkey and Turkmenistan at the level of the Ministers of Culture signed a protocol of intentions in June 1992 in Istanbul, aimed at "the moral unification of the Turkic-speaking peoples, taking into account the changing world conditions." The agreement on the principles and organizational structure of TURKSOY was signed on July 12, 1993 in Alma-aty. The constituent entities of the Russian Federation - Altai, Bashkortostan, Khakassia, Tatarstan, Tyva, "Turkish Republic of Northern Cyprus" and Gagauzia were included in the organization as observers. (B. Oran, M. Aydın, G.T. Alpkaya, E. Tellal, M. Frrat [4], B. Oran, Ü. Ünsal [5], H. Acar [6]). However, initially positioned as a Turkic analogue of UNESCO, TURKSOY at first was mainly engaged in publishing materials in journals about the great Turkic cultural figures (D.B. Malysheva [7, p.51]). 
By the early twenties of the XXI century, the Central Asian countries had accumulated thirty years of experience of interaction with many countries of the world, including Turkey. (G.A. Vakhitova [8], M. Yusupov [9]). One of the main forms of this experience was humanitarian cooperation, which can be characterized by the following features.

The first feature of this cooperation can be identified as weak elaboration and low correlation between the strategy and tactics of humanitarian cooperation between Turkey and the countries of Central Asia. If the tactical "here and now" steps of Turkey are justified and more or less implemented, then the strategic plans change from year to year. In the first years of independence of these countries, Turkey built colossal and overly ambitious plans for joint activities in almost all spheres of life of the Central Asian countries, and even created a program by the leaders of Turkey for the soonest integration of the Central Asian Turkic states into a single Turkic spatial continuum. At the same time, even the ethnic proximity of Tajikistan to Iran did not create obstacles. An example of the scale and scope can be humanitarian cooperation within the framework of providing assistance to Turkey for the development of Islam and Islamic education in Central Asia. In 1991, within the framework of a large student project from five Turkic republics, 10 thousand scholarship students were sent to the Republic of Turkey at the expense of Turkey. On the other hand, schools and universities began to open in Central Asian countries in accordance with Memorandums of Understanding and Agreements for Cooperation in Education (Z.B. Avşar, F. Solak [10, p.34]). The scale also applied to secular education In the first half of the 1990s., 1971 students, 5935 bachelor students, 377 master students began to study in Turkish secondary educational institutions. In total, in the 1990s, more than 18 thousand students from the countries of the region, including more than 300 diplomats, received education in Turkish universities. In 1992 International Kazakh-Turkish University named after H.A. Yasavi (Shymkent, Republic of Kazakhstan) and KyrgyzTurkish University "Manas" (Kyrgyzstan) were created. More than ten Turkish lyceums have opened in the countries of the region.

However, as a result of haste in choosing the direction of education, organizational miscalculations, the difficulty of getting used to a new way of life, the students returned to their homeland without completing their studies [10, p.41].

Another cultural project of Turkey in humanitarian cooperation was television and the media. On April 27, 1992, the satellite channel TRT Television of Eurasia (then referred to as TRT-Turk) started broadcasting $(\mathrm{H}$. Acar [6, p.52]). But at the end of the tenth years of the XXI century, there is a worldwide tendency - a reduction in the youth television audience, its transition to the Internet environment.

In 1993, at a spelling conference, it was decided to create a Turkic alphabet from Latin letters, but the project was not implemented until 2019. As a result of the creation and discussion of the Turkic alphabet in 1993, the Uzbek authorities decided to transfer the Uzbek language from Cyrillic to Latin, and the Government of Kazakhstan announced in January 2015 that the Latin alphabet will replace the Cyrillic alphabet as a writing system for the Kazakh language by 2025 [6, p.61].

With the cooperation of the Turkish Ministry of Religious Affairs and the Turkish Religious Fund, mosques, cultural centers and theological faculties began to open in the Turkic republics. New mosques and centers were erected through the mediation of the Ministry of Religious Affairs and, together with the Turkish Religious Fund, the restoration of religious sites (objects of Islamic culture) was carried out. Theological faculties were opened in Kyrgyzstan and Turkmenistan (K.H. Karpat [11, p.112]).

The organization TURKSOY, which positioned itself as a Turkic analogue of UNESCO, had problems, but from the first days of its existence was unable to develop its multifaceted and multi-vector activity. On October 3, 2009 , it was subordinated to the Turkish Council and on October 16-17, 2009, its name was changed to "International Turkic Cultural Organization". But the influence of this organization is rather limited - no more than cultural events and publications (for example, analysis of the life and scientific activities of the famous Arabist Islamist, Ubaidulla Uvatov, as well as his contribution to the study of the scientific heritage of Central Asian scientists - Amir Temur, Imam of Termezi, Khakima Termezi, Abul Muina Nasafi, Mahmud Zamakhshari) (N.R. Karimov [12, p.64]).

Thus, Turkey expresses a multifaceted initiative in cooperation, but tactically, some programs are not completed. As a result, we summarize that Turkey has a long-term strategy in Central Asia, but it is important to analyze tactical measures.

This also determines the second feature of Turkey's humanitarian cooperation with the Central Asian countries - the absence of a system of humanitarian cooperation and the dynamics of the goals of Turkey's humanitarian cooperation with the Central Asian countries. The dynamics of goals - from the great task of creating the Turkic world in Europe and Asia (the idea of "neo-Ottomanism") to real and mundane landmarks at the end of the tenth years of the XXI century - can be called flexibility depending on the change in influence in Central Asia - the growth of the real influence of the Russian Federation and the PRC and the decline USA and EU countries and NATO. But the absence of a systematic approach to humanitarian cooperation 
between Turkey and the countries of Central Asia is emphasized by many researchers - I.I. Ivanova [13, p.46], Sh.M. Sultanov [14, p.41], Sh.R. Kashaf [15, p.166], R. Veitsel [16, p.30], V.A. Moskalenko [17-18], G. Bayraktar [19, p.22].

This is the third feature of Turkey's humanitarian cooperation with the countries of Central Asia - Turkey's desire to do as much as possible when its own funds and resources are insufficient, including a limited number of representatives of Turkish business wishing to invest in the economy and economy of the Central Asian countries.

In 1995, Turkey accounted for $22 \%$ of exports and $29 \%$ of imports of the region's states from Asia. The most actively developed interaction of young states with Turkish business in the construction sector. Turkish companies took part in projects related to the transfer of the capital of Kazakhstan from Alma-Aty to Akmola (Astana). By the end of the 1990s, 2,500 Turkish enterprises operated in the region. The volume of Turkish investments reached $\$ 8.4$ billion, and the total amount of construction contracts reached $\$ 4$ billion. Along with that, Turkey jointly developed the light and chemical industries, the energy sector of the Central Asian countries. Turkish economists and businessmen became economic advisers to the President of Turkmenistan S. Niyazov and the President of Kazakhstan N.A. Nazarbaev.

The leadership of Uzbekistan was oriented economically and culturally towards Turkey. In early 1992, the Uzbek government asked Turkey to represent Uzbekistan's interests in countries with which it did not have diplomatic relations. I.A. Karimov paid an official visit to Ankara in 1991, and in 1992 Turkish Prime Minister Suleiman Demirel visited Tashkent (F.T. Rashidov. [20, p.16]). Turkey has allocated assistance to Uzbekistan in the amount of $\$ 700$ million for the purchase of Turkish goods (grain, sugar, medicines and medical equipment). By the mid-1990s, Turkey ranked first in terms of foreign investment in Uzbekistan. In July 1992, I.A. Karimov put forward the thesis of the "Ataturk path", which he called the countries of Central Asia to follow in order to achieve the same development success as Turkey (Z.I. Munavvarov, [21, p.106]).

At the same time, according to I.I. Ivanova [13, p. 46], the level of relations between Turkey and Central Asia in the period from 2001 to 2006 remained politically at a rather low level, and therefore reduced humanitarian cooperation. And only by the end of the 2000s, Turkey came to the understanding of revising political approaches to the countries of Central Asia. Turkey came to the conclusion that it cannot provide the countries of Central Asia with high investment or resource potential as global powers (USA, EU, RF, PRC) (K. İnat, A. Aslan, B. Duran [22, p.79]).
On the other hand, even weakening political contacts, Turkey studied Central Asia in Turkish research centers and recorded an increased growth of scientific interest in the Central Asian region in the 2000s in the context of the implementation of the new foreign policy doctrine, as well as in the framework of the implementation of the vision of Turkey's doctrine 2023 (A. Aydıngün, Ç. Balım $[23$, p.124]).

The fourth feature of Turkey's humanitarian cooperation with Central Asian countries is the priority of their own interests, interest in permanent unchanging double alliances (Turkey - Kazakhstan, Turkey Kyrgyzstan, Turkey - Tajikistan, Turkey - Turkmenistan, Turkey - Uzbekistan), while there should be no other alliances and blocks ("be friends only with us") while Turkey has the right to change its goals, intentions and allies.

An example is the study by Turkey of the issue with the countries of Central Asia in the early 90s of the twentieth century on the diplomatic recognition of the Turkish Republic of Northern Cyprus (M. Özçalık, A. Şahin [24, p.28]).

Another example is the complication of relations between Turkey and Kyrgyzstan in connection with the demand by Turkey to close Turkish lyceums on the territory of Kyrgyzstan as affiliated with the Hizmet organization (F. Gulen), in response Kyrgyzstan stated that this is an internal affair of the republic (G. Özkan $[25, \mathrm{p} .106])$.

The main issue in the humanitarian cooperation between Turkey and the countries of Central Asia was the Islamic issue and the problem of Islamic education (A.M. Pulatov [26, p.39], F.O. Kuisinova [27, p.67]). Turkey presented its own model of progressive secularization from a completely Islamic country to a republic as one of the main models of the state, combining the two main institutions of society and the state - Islam and education, as well as the interaction of Muslim religious organizations with various institutions of the secular state. This model was actively presented to the countries of Central Asia as the only possible one. But at the same time, Turkey pursued the ideas of neo-Ottomanism and Pan-Turkism, the revival of a single Eurasian Turkic space led by Turkey. The incomplete congruence of this idea on the part of the Central Asian countries in the 90s of the twentieth century caused a decrease in interest in these countries, a decrease in activity in matters of financial investment and humanitarian cooperation on the part of Turkey (V.A. Avatkov [28, p.106], E.F. Troitsky [29, p.85], A.V. Bakustin [30, p.180]).

All attempts of Turkey to revive the pan-Turkist policy in the countries of Central Asia and their unification on the principles of ethnic and linguistic community have not been implemented over the past thirty years (1991-2020) and have not been actively 
implemented by the leadership of the Central Asian states. Therefore, Turkey has become more pragmatic in its goals.

\section{CONCLUSION}

Identified markers for researching the role of humanitarian cooperation in the development of interethnic relations (strategic and tactical goals of humanitarian cooperation; actors and motivators of this process, the presence of third countries - customers, interested parties, allies, etc.; the state of the economic, financial, socio-political and national spheres of the state - donor of cooperation; resources and potentials of both the recipient country and the donor power of humanitarian cooperation, the latter's obligations to other countries and blocks, etc.) were applied to the comparative political study of the problem of interethnic relations and humanitarian cooperation between Turkey and the Central Asia.

As a result, we obtained the following features of Turkey's humanitarian cooperation with the countries of Central Asia:

- poor elaboration and low correlation of the strategy and tactics of humanitarian cooperation between Turkey and the countries of Central Asia;

- the absence of a system of humanitarian cooperation and the dynamics of the goals of Turkey's humanitarian cooperation with the countries of Central Asia

- Turkey's desire to do as much as possible with the lack of its own funds and resources, including a small number of representatives of Turkish business willing to invest in the economy and economy of the Central Asian countries;

- priority of their own interests, interest in permanent unchanging double alliances (Turkey - Kazakhstan, Turkey - Kyrgyzstan, Turkey - Tajikistan, Turkey Turkmenistan, Turkey - Uzbekistan), while there should be no other alliances and blocks ("be friends only with us") while Turkey has the right to change its goals, intentions and allies.

The revealed features of humanitarian cooperation between Turkey and the countries of Central Asia make it possible to characterize the role of this cooperation in the formation of interethnic relations between Turkey and the countries of Central Asia as ambiguously assessed, having both positive and negative aspects. The first include the recognition by the world community of the Central Asian countries, the integration of the Central Asian countries into the world market, and the acquisition of international experience as a state with an independent political status. The second is Turkey's authoritarian demand for a primary place in international relations of the Central Asian countries, the imposition of an IslamicTurkic position on many issues of the life of the population of Central Asian countries, the inconsistency and inconsistency of cooperation, the priority of Turkish interests of cooperation.

At the same time, we note that this role is more positive and constructive than negative and destructive, since humanitarian cooperation between Turkey and the countries of Central Asia has enormous resources and potential in the integration of socio-political, ethnocultural, Islamic-educational and trade-economic activities of Turkey and countries Central Asia. In the future, this can really contribute to the implementation of the slogan of R.T. Erdogan ("six peoples - one nation"), but subject to the state sovereignty of each Central Asian country, taking into account the interests of not only the countries of the region, but also the neighboring countries - the Russian Federation, China, Afghanistan, etc.

\section{REFERENCES}

[1] A.A. Mustafin, Political science: a dictionary of modern terms and expressions, Angarsk: Publishing house: AGTA, 2012, 168 p.

[2] A.A. Velikaya, International humanitarian cooperation: political aspects of domestic and Western approaches, Law and governance XXI 3(24) (2012) pp. 63-72. Retrieved from: https://elibrary.ru/item.asp?id=18875625

[3] Z.S. Pulatkhodjaev, The process of forming an international sub-region in Central Asia, Bulletin Social-Economic and Humanitarian Research Vol. 5 Iss. 9 (2020) 82-90. DOI: DOI: https://doi.org/10.5281/zenodo.3652975

[4] B. Oran, M. Aydın, G.T. Alpkaya, E. Tellal, M. Fırat, Türk Dış Politikası - Cilt 2 (1980-2001) (Turkish Foreign Policy Volume 2 (1980-2001). Istanbul: Iletişim yayınları, 2001, 637 p. (In Turkish).

[5] B. Oran, Ü. Ünsal, Türk Dış Politikası Cilt 3 (20012012) (Turkish Foreign Policy Volume 3 (20012012)). Istanbul: Iletişim yayınları, 2013, 885 p. (In Turkish).

[6] H. Acar, Türk Dış Politikas, Turkish Foreign Policy, Ankara: Nobel Akademik Yayıncılık, 2020, 636 p. (In Turkish).

[7] D.B. Malysheva, International political interaction of the Central Asian states with Turkey and Iran, Russia and the new states of Eurasia 3 (2017) 4658. Retrieved from: https://elibrary.ru/item.asp?id=30281386

[8] G.A. Vakhitova, Interaction of Turkey with the countries of Central Asia, Izvestiya vuzov 
(Kyrgyzstan) 1 (2010) 189-192. Retrieved from: https://elibrary.ru/item.asp?id=27808754

[9] M. Yusupov, Organizational, legal, economic and political aspects of diplomatic relations between Turkey and Central Asia, Bulletin of Social, Economic and Humanitarian Research 7(9) (2020) 53-61.

DOI: https://doi.org/10.5281/zenodo.3841983

[10] Z.B. Avşar, F. Solak. Türkiye ve Türk Cumhuriyetleri. Turkey and Turkic Republics, Ankara: Vadi Yayınları, 1994, 286 p. (In Turkish).

[11] K.H. Karpat, Türkye ve Orta Asya, Turkey and Central Asia, Istanbul: Timaş Yayınları, 2014, 304 p. (In Turkish).

[12] N.R. Karimov The true successor of the great scientists of Central Asia, Bulletin SocialEconomic and Humanitarian Research Vol. 7 Iss. 9 (2020) $62 \quad-69 . \quad$ DOI: https://doi.org/10.5281/zenodo.3841989

[13] I.I. Ivanova. Turkey in Central Asia: Partner or Rival? Asia and Africa today 7 (2019) 39-47. DOI: https://doi.org/10.31857/S032150750005567-5

[14] Sh.M. Sultanov, Turkey's geostrategy in the Central Asian region: the failure of the Pan-Turkism policy and the lessons of economic pragmatism, Economics and Management: Problems, Solutions Vol. 2 Iss. 9 (2017) 39-47. Retrieved from: https://elibrary.ru/item.asp?id=30296476

[15] Sh. F. Kashaf, Dissemination of the experience of the institutional organization of Islamic education in the foreign policy context of interaction between Russia, Turkey and the countries of Central Asia, State and municipal formation. Scientific notes of NCAPA 1 (2017) 160-172. Retrieved from: https://elibrary.ru/item.asp?id=28843225

[16] R. Veitsel, Turkey's influence on the culture and education of Central Asian countries, Islam in the modern world: domestic and international political aspects 1(33) (2014) 26-32. Retrieved from: https://elibrary.ru/item.asp?id=24400919

[17] V.A. Moskalenko, The role of the Turkish Republic in solving regional conflicts in international relations, M.: Publishing house Nestor-History, 101 p.

[18] V.A. Moskalenko, Impact of the consequences of regional conflicts in the Middle East on the policy of the Republic of Turkey, Ed. A.V. Shtanova, M.: Nestor-History, 2018, 208 p.

[19] G. Bayraktar, Orta Asya ve Türkiye'nin Güvenlik Stratejileri, Central Asia and Turkey's Security Strategies. Istanbul: Bilgeoğuz Yayınları, 2008, 286 p. (In Turkish).
[20] F.T. Rashidov, Tolerance, International and Religious Relations in Uzbekistan: History, Present and Prospects, Bulletin Social-Economic and Humanitarian Research Vol. 7 Iss. 9 (2020) 14-23. DOI: $\underline{\text { https://doi.org/10.5281/zenodo.3817018 }}$

[21] Z.I. Munavvarov, Features of the religious and spiritual policy of the Republic of Uzbekistan: current trends, Bulletin of socio-economic and humanitarian research Vol. 4 Iss. 6 (2019) 104-113. DOI: https://doi.org/10.5281/zenodo.3594466

[22] K. İnat, A. Aslan, B. Duran, AK Parti'nin 15 Y1lı Dış Politika, 15 Years of Justice and Development Party Foreign Policy, İstanbul: SETA Kitapları, 2017, 553 p. (In Turkish).

[23] A. Aydıngün, Ç. Balım, Bağımsızlıklarının Yirminci Yılında Orta Asya Cumhuriyetleri Türk Dili Halklar. Türkye ile ilişkiler, Central Asian Republics in the Twentieth Year of Their Independence, Turkish Language People Relations with Turkey, Ankara: Atatürk Kültür Merkezi, 2012, 682 p. (In Turkish).

[24] M. Özçalık, A. Şahin, Orta Asya Cumhuriyetleri ve Türkiye, Central Asia and Turkey, Bursa: Ekin Kitabevi Yaınları, 2014, 92 p. (In Turkish).

[25] G. Özkan, Turkish Foreign Policy in Central Asia and The Caucasus Within The Context of The New Great Game and Energy Security, Bursa: Ekin Kitabevi Yayinlari, 2010, 128 p. (In English).

[26] A.M. Pulatov, The Islamic factor in the modern political life of the countries of Central Asia, Bulletin Social-Economic and Humanitarian Research Vol. 7 Iss. 9 (2020) 35-42. DOI: https://doi.org/10.5281/zenodo.3831465

[27] F.O. Kuisinova, The role and political image of the Organization of the Islamic Conference in the system of international relations, Bulletin of socioeconomic and humanitarian research Vol. 2 Iss. 4 (2019) 61-68. DOI: https://doi.org/10.5281/zenodo.2647705

[28] V.A. Avatkov, Turkic world and Turkic organizations, World politics 2 (2018) 11-25. DOI: https://doi.org/10.25136/2409-8671.2018.2.26047

[29] E.F. Troitskiy, Turkey's policy in Central Asia (1992-2000), Bulletin of Tomsk State University 328 (2009) 84-88. Retrieved from: https://elibrary.ru/item.asp?id=13764870

[30] A.V. Baskutin, Turkey, Russia and the Central Asian states in the XXI century, Russia and the modern world 2(9630) (2009) 175-186. Retrieved from: https://elibrary.ru/item.asp?id=12228169 